\title{
A filosofia e os anos 1960
}

Philosophy and the 1960s

Pedro Duarte de Andrade

Efetivamente, o filósofo parou de querer falar do que existe eternamente. Ele tem a tarefa bem mais árdua e mais fugidia de dizer o que passa.

Michel Foucault, 1967

\section{A filosofia em uma década contraditória}

Os anos 1960 são mais do que a contabilidade historiográfica pode enumerar. Linearmente concebida, a década vai de 1960 até 1969. Entretanto, o que nela ocorreu no tempo das experiências - com significados e pensamentos - não pode ser reduzido a dados e fatos, em um apelo positivista. Muitos filósofos da época, aliás, atacaram a historiografia que tratava o tempo de maneira homogê-

Pedro Duarte de Andrade é doutor em Filosofia pela PUC-Rio e professor adjunto de Filosofia da UniRio, Rio de Janeiro, Brasil (p.d.andrade@gmail.com).

Artigo recebido em 4 de abril e aprovado para publicação em 12 de abril de 2012. 
nea, como se os anos fossem números cujos conteúdos em nada alterassem o seu relevo. O ensaio aqui escrito fala dos anos 1960 buscando essa topografia do tempo, que já se vê a partir do ponto histórico em que estamos e que se exime da exigência de recuperação do passado como ele supostamente foi de fato. Até porque, "fato" é já uma palavra, um conceito. Quando falamos de fatos, estamos em uma interpretação, pois temos um significado em mente. Nietzsche dizia que não há fatos, mas apenas interpretações.

A frase soa exagerada, mas o ponto é que só temos acesso aos fatos já envolvidos em um sentido. Pode-se catalogar o que ocorreu politicamente em 1964 no Brasil, por exemplo, contando só datas e nomes. Entretanto, se chamamos tais fatos de "golpe" ou de "revolução" é o que determina sua verdade e sua narração. Logo, a verdade diz respeito à interpretação dos fatos, e não aos fatos.

No caso aqui em questão, há ainda um agravante quanto a qualquer pretensão de retomar o que já foi tal como aconteceu, pois o autor nem sequer viveu a época. E, como os anos 1960 são relativamente recentes, muitos dos que vão ler as linhas aqui escritas, esses sim, viveram a época, podendo julgá-las com o privilégio de ter estado lá. Já o autor experimentou apenas vestígios deixados por tal década na cultura. Não foram poucos, tanto que já se chegou a dizer que 1968 foi o ano que não terminou (Ventura, 1988). Da música ao cinema, da literatura às artes plásticas, da política à moral, tudo foi mexido na época. O objetivo deste ensaio é destacar especialmente as transformações filosóficas que atravessavam essas outras, apontando, quando for possível, seus cruzamentos. Embora ideias filosóficas possam ultrapassar o momento em que foram criadas, elas não se situam fora da história, entretendo com esta contatos muito complexos e nada mecânicos, porém sempre existentes.

Tanto em termos históricos quanto filosóficos, os anos 1960 podem ser vistos, hoje, como momento de passagem: dos ideais utópicos revolucionários que continham promessas grandiosas sobre o futuro para práticas menores de rebeliões críticas dentro do presente. Desse ponto de vista, os anos 1960 deram os últimos sinais contundentes da época moderna, ao mesmo tempo que já anunciavam uma nova fase em que entrava o mundo ocidental, fase determinante para a atualidade. Era o começo do ocaso da modernidade, cuja expressão, segundo o poeta mexicano Octavio Paz (1984), estava no declínio da idéia de revolução, uma vez que programas para organizar a sociedade futura já se enfraqueciam e cresciam rebelióes específicas, concentradas no ataque a problemas pontuais da situação do presente. Os anos 1960 foram de luta, muita luta, e de tentativas de resistência ao capitalismo econômico e ao autoritarismo político, que por vezes andaram de mãos dadas. Mas a forma de lutar já não era apenas aquela à qual a modernidade, por cerca de dois séculos, nos havia acostumado.

É claro que a época ainda mantinha muito da modernidade. Como toda fase de transição, ela possui um rosto ambivalente. Se a década de 1950 erguia-se 
dos abalos da Segunda Guerra Mundial com calma, a agitada década de 1960 formulava a sua descrença em programas históricos que, baseados na razão e na ciência tecnológica, prometiam um futuro mais justo. Era colocada em questão a crença em uma história linear cujo sentido seria o progresso. O Iluminismo moderno, ao invés de trazer o Estado Cosmopolita de que falara Kant (2004) ao fim do século XVIII, testemunhara o imperialismo do Estado Nazista. E o "negrume não surgiu no deserto de Gobi", como dizia George Steiner em 1966, mas "no cerne da civilização europeia", ou seja, "os gritos dos assassinados ecoaram a pouca distância das universidades; o sadismo aconteceu a uma quadra dos teatros e museus" (1988: 14). Por sua vez, a tentativa do Estado Socialista não tivera destino diferente, colocando sob suspeita promessas de outra vertente da filosofia moderna, aquelas vindas do sistema de Marx.

Os anos 1960 tiveram que começar a enfrentar a decepção, a despeito das declarações de Jean-Paul Sartre em contrário, com o projeto socialista soviético. O filósofo existencialista francês tentava salvar a dignidade daquele regime implantado, mesmo quando Lênin e Trótski já se tinham tornado passado e ficara só Stálin, com a sanha de um Estado cujo caráter totalitário, conforme apontou Hannah Arendt (1989), não era tão distinto do nazismo. Campos de concentração e de trabalho, por exemplo, estavam presentes em ambos, assim como o terror e a tortura. Perseguição e censura também. De resto, tanto o nazismo alemão - inspirado em Darwin e no evolucionismo biológico - quanto o socialismo soviético - inspirado em Marx e no progresso social - tinham como justificativa ideológica uma história linear portadora do melhor futuro para a humanidade, ainda que com a diferença relevante de que no primeiro caso tal futuro seria uma raça superior e no segundo seria uma sociedade sem classes.

Sendo assim, a década de 1960, embora seja marcada pelo marxismo, abre as portas para sua crise. O marxismo ortodoxo cede espaço para outro, heterodoxo, e por vezes mais criativo. Marx continua referência forte, como prova a obra de Althusser, mas sofre também inesperadas adaptações, como no situacionismo de Guy Debord sobre a sociedade do espetáculo e no estruturalismo. Mesmo porque, a história sugeria tal necessidade. Países avançados industrialmente não tiveram revoluções proletárias, como previa a teoria de Marx sobre as contradições do capitalismo, um sistema que, pela lógica, deveria explodir, ou melhor, implodir onde fosse mais desenvolvido, pois ali mais desenvolvida seria a oposição entre capital e trabalho que o caracteriza. Foi em nações economicamente atrasadas desse ponto de vista que surgiram insurreições mais ou menos ligadas ao marxismo, como a Rússia e a China. Nesses casos e em outros menos centrais, o papel de classe revolucionária não foi, porém, exercido pelo proletariado, e sim por grupos para os quais Marx dera pouca atenção.

Entre tais grupos, estava um que seria protagonista nos anos 1960. Eram os estudantes. Não por acaso: a década anterior, se não criou o que conhecemos 
como juventude, pelo menos a consolidou. Até então, não havia uma fase da vida individual tão nitidamente marcada como transição entre a criança e o adulto. Tal passagem era mais direta, e não tinha em torno de si cultura específica e um mercado tão específico quanto. Isso foi uma criação do rock, de Chuck Berry e de Elvis Presley, assim como do cinema de James Dean. Em suma, os Estados Unidos da década de 1950 fundavam a cultura da juventude (Savage, 2007), cuja vocação, na verdade, era global. Preparava-se a condição de possibilidade para que, nos anos seguintes, essa mesma juventude, tendo no estudo a sua ocupação principal, procurasse direitos próprios na sociedade, como a liberdade de expressão, e protestasse com rebeliões, embora seus problemas não tivessem natureza econômica em primeiro lugar, mas sim moral e cultural.

Esses estudantes, mas não só eles, falavam muito de revolução. No entanto, despontavam já suspeitas filosóficas quanto a seu significado, como as que Hannah Arendt colocara em 1963 com Sobre a revolução, obra que recebeu pouca atenção na época, talvez por seu diagnóstico nada triunfalista em relação ao destino dessa forma moderna de política. Eram discutidas no livro a Revolução Americana e a Revolução Francesa. Embora mais generosa com a primeira do que com a segunda, em ambas Hannah Arendt destacou, positivamente, o momento de liberdade que proporcionaram e, negativamente, sua incapacidade de, após a ruptura, formar instituições onde tal liberdade persistisse. A espontaneidade da ação era perdida, em prol da normatização da vida diária com seus afazeres sociais. Embora o livro tenha caráter histórico, sua introdução mostra um ponto de partida contemporâneo, ao anunciar que as revoluções determinaram toda a história do século XX. "Mesmo que conseguíssemos mudar a fisionomia deste século a ponto de deixar de ser um século de guerras, com toda certeza continuará como um século de revoluções" (Hannah Arendt, 2011: 43).

Essa aproximação entre guerra e revolução, feita por Hannah Arendt, tinha sua confirmação na história, mas seu propósito filosófico era apontar o elemento comum a ambas as experiências: a violência. Isso era bastante grave para uma autora que não só era apaixonada pela política como concebia que esta terminava quando a violência começava, pois então se exaure a fala, a expressão verbal, o discurso. "O ponto aqui é que a violência é incapaz de fala, e não apenas que a fala é impotente diante da violência", afirma Hannah Arendt, completando que "uma teoria da revolução, portanto, só pode tratar da justificação da violência porque essa justificação constitui seu limite político; se, em vez disso, ela chega a uma glorificação ou a uma justificação da violência enquanto tal, já não é política, e sim antipolítica" (2011: 45). Portanto, a guerra não é a continuação da política por outros meios, e sim uma ruptura com a política.

Nos anos 1960 em geral, e no Brasil em particular, essa discussão seria muito viva. Até que ponto a violência seria legítima para a luta política? Marx, já 
no século XIX, mostrara a ligação entre mudanças radicais na história e a violência. Logo, se a revolução era desejada, talvez fosse preciso acolher a violência que ela traria. Muitos seguiam esse raciocínio lógico sem problemas já no século XX, mas outros não, e estes eram por vezes desqualificados por aqueles, ao deixar de fazer os sacrifícios morais que as grandes mudanças exigiriam para o nascimento de um mundo novo. A década de 1960, em sua luta pela liberdade, também foi, paradoxalmente, carregada de certa intolerância. Era o preço que se pagava pelo radicalismo. No caso do Brasil, a tensão da vida sob o regime ditatorial tornava esses dilemas mais difíceis, inclusive o do uso da violência com a luta armada. Afinal de contas, fora o próprio Estado que, em primeiro lugar, rompera com a dimensão política ao empregar, legal e ilegalmente, a força, até militar, contra aqueles que se opunham a ele através das palavras.

Onde o mundo teve rebeliões naquela época, e não apenas no Brasil, aparecia a questão da violência. Tomada certa distância dos campos de concentração, da guerra e da tortura dos anos 1940, pouco a pouco a década de 1960 tornou-se menos avessa ao uso da violência. Sartre, por exemplo, engrossou as fileiras dos que o defendiam, ao apoiar os escritos de Frantz Fanon que tinham tal intento. Eis porque Hannah Arendt viria a criticar a Nova Esquerda e o "Black Power" entre os estudantes sempre que as teorias elogiavam a violência e os protestos a praticavam, o que eclipsava a sua "mais pura coragem, um espantoso desejo de ação e uma não menos espantosa confiança na possibilidade de mudança" (Hannah Arendt, 1999: 103). Na contramão de Fanon, que ganhara notoriedade, Hannah Arendt repudiava a ideia de que violência compensa, e o que ela prezava, nas rebeliões da época, era antes a tentativa de uma democracia participante, e não os ganhos pragmáticos.

O tema das revoluções e da violência era tão importante que mesmo estudos sobre a ciência tocavam nele. Thomas S. Kuhn, ao tratar da estrutura das revoluções científicas, comparava-as às políticas. Em ambas estaria em jogo, quando se enfrenta uma crise devido a desajustes em funcionamentos epistemológicos e institucionais, a mudança de um paradigma, isto é, um corte entre épocas que não faz da posterior o resultado de um acúmulo temporal progressivo da anterior. Revoluções são cortes que fazem uma troca de paradigmas, impossibilitando a comparação entre antes e depois, já que os pressupostos seriam distintos em cada caso, e sem a chance de um legislador neutro superior para julgar. Como o embate se dá entre dois paradigmas diferentes, eles não podem reconhecer uma mesma esfera que regule o conflito, daí a tendência a recorrer à força (Kuhn, 1999: 127). É o radicalismo do conflito que leva à situação violenta das revoluções, pois não se acha outra solução. Entre o paradigma do passado e o novo parece não haver conciliação, negociação, diálogo. 
Esse radicalismo, tão presente nos anos 1960, explica a paradoxal intolerância da época: para alguns, a conduta na vida privada podia ser uma escolha moral livre, mas a posição na vida política devia ser comprometida com um ideal, em geral com a mudança de um paradigma. Divórcio e sexo livre, tudo bem. Mas alienação jamais. Era preciso ter consciência política, o que significava um engajamento nem sempre pela democracia, mas pelo comunismo, o que era indicado pela expressão "ditadura do proletariado" e agravado pela bipolaridade mundial da Guerra Fria. Não foram poucas as vezes, embora também não tenham sido todas, em que jovens da década de 1960 tiveram sua visão de mundo engolfada, mais do que orientada, pela ideologia. $\mathrm{O}$ apoio a figuras revolucionárias autoritárias, como Mao Tse-Tung, é a prova. E o sucesso do grande filme $A$ chinesa, de Jean-Luc Godard, enraizou-se não só em sua estética de vanguarda, mas na sua conotação política também.

Diga-se de passagem que a tentativa de pensar a arte por um viés engajado fez vítimas de grande beleza. No Brasil, o exemplo foi a disputa, no Festival da Canção de 1968, entre "Sabiá", de Tom Jobim e Chico Buarque, e "Pra não dizer que não falei de flores", de Geraldo Vandré. Embora a primeira tenha vencido o festival, foi vaiada violentamente no Maracanãzinho, pois muita gente torcia pela segunda, uma canção de protesto. Já "Sabiá", embora falasse de exílio, tinha caráter lírico, o que fez dela competidora em desvantagem perto de versos urgentes, que podiam ser cantados em uníssono, como "quem sabe faz a hora, não espera acontecer". Entre a poesia e a palavra de ordem, a segunda por vezes levou a melhor nos anos 1960.

Na minissérie Anos rebeldes, um belo retrato do Brasil da época feito já nos anos 1990, o mais inteligente autor de telenovelas nacionais, Gilberto Braga, fez com que o casal protagonista travasse esse debate: o personagem de Cássio Gabus Mendes, João, defendia Vandré, só que Maria Lúcia, interpretada por Malu Mader, preferia “Sabiá". No último capítulo, após passarem anos distantes e João voltar do exílio ao qual foi obrigado por ter entrado na luta armada, eles não acabam juntos. Mas João confessa que a música de Chico e Tom era a mais bonita. Passada a pressão política da vida sob a ditadura, era possível avaliar de forma mais livre o valor estético das músicas, sem submetê-las ao critério do engajamento. Infelizmente, a partir de 1968, a repressão, a censura e a perseguição brasileiras já endureciam, com o AI-5. Nesse contexto, era difícil ter distanciamento para apreciar a beleza da arte com autonomia, ou seja, sem subordiná-la à luta direta contra a ditadura, que àquela altura deixara de ser envergonhada (Gaspari, 2002a) para se tornar escancarada (Gaspari, 2002b). Tempos difíceis não deixam escolhas fáceis para aqueles que os vivem. Quem viveu os anos 1960, especialmente naqueles muitos países que sofreram golpes militares, precisava fazer escolhas estéticas, morais e políticas em um mundo difícil. 
Como se vê, a década de 1960 foi, sobretudo, multifacetada: sonho e pesadelo, esperança e medo, liberdade e repressão, arte e guerra, política e ditadura, passado e futuro, utopia e realidade, acolhimento e intolerância. Como os atores sociais que se colocavam de cada um desses lados nem sempre eram os mesmos, dependendo da questão em pauta, a época foi não apenas multifacetada, mas por vezes contraditória. E, sobretudo, foi cheia de transformações, que não ficaram restritas a um só país, mas avançaram sobre o mundo ocidental, em ritmos variados dependendo do lugar. Se os anos 1960 não conheciam a globalização e a internet, tinham rádio, jornais ágeis e um mercado eficiente para distribuir produtos e livros, além da televisão, mais acanhada do que hoje, porém em franco crescimento. Tudo o que acontecia viajava e passava a ser conhecido por boa parte do mundo independentemente da localização geográfica, ainda mais se compararmos com a situação da primeira metade do século XX.

Nesse cenário, são abundantes as direções que a filosofia toma nos anos 1960. Jacques Derrida começa sua trajetória com $A$ escritura e a diferença e Gramatologia, Gilles Deleuze escreve sobre Nietzsche e muito mais, Paul Ricoeur estuda a questão da interpretação, Emannuel Lévinas publica Totalidade e infinito. A França é o centro do pensamento: Lacan na psicanálise, Pierre Bourdieu na sociologia e Lévi-Strauss na antropologia estruturalista dão o tom. Sartre e o existencialismo ainda têm seu lugar. Althusser lê Marx. Nos Estados Unidos, os exilados, como Hannah Arendt, produzem muito. Adorno, de volta à Alemanha, escreve a Dialética negativa, en tre outras obras. Jürgen Habermas, que trabalhara com ele, publica em ritmo veloz. Heidegger, já mais velho, ainda está ativo e continua seu pensamento sobre o ser e a história, que muito influenciou essa geração. São tantos os filósofos trabalhando na época que se torna impossível resumi-los, mas poucos foram tão ligados a ela como Herbert Marcuse e Michel Foucault, que por isso terão destaque neste ensaio.

\section{Herbert Marcuse e o princípio do prazer}

O cenário dos Estados Unidos nos anos 1960 é emblemático da passagem que marcou a época, misturando a permanência de idéias revolucionárias com a prática de rebeliões que nem sempre tinham programas de transformações globais na estrutura econômica da sociedade. Não era a identidade de classe que contava mais, conforme a orientação marxista, e sim outras, como a racial ou a sexual. O que estava em pauta eram causas como a dos direitos civis, buscando dar aos negros os mesmos direitos que tinham os brancos no país. Era a época de Martin Luther King, de Malcom X e de um sonho que era mais de inclusão do que de transformação no sistema. A igualdade racial não exigia uma revolução que mudasse o capitalismo norte-americano. 
Conforme analisou o filósofo John Searle (2008), os protestos estudantis que tiveram começo em 1964 na universidade californiana de Berkeley - e que marcaram a época - receberam seu impulso primeiro dos movimentos dos direitos civis, cuja força já estava clara em 1963. Os jovens estudantes da classe média, sem maiores preocupações financeiras, sensibilizaram-se com questões morais, e podiam dedicar seu tempo a elas. Eram predominantemente brancos, mas foram tocados por injustiças contra os negros e quiseram combatê-las. Para tanto, mobilizaram-se para desafiar as estruturas burocráticas universitárias, dando prova de força. E assim eles inauguraram uma forma de fazer política até então praticamente inexistente, já que exercida fora dos quadros partidários e sem interesses trabalhistas diretos, como os que orientavam os sindicatos de classes. $\mathrm{O}$ caráter moral igualitário e libertário das reivindicações, e a estratégia dos protestos, davam um ar de novidade ao que acontecia, posteriormente misturado à contracultura e às críticas à Guerra do Vietnã. De certa forma, os anos 1960 estavam nascendo ali.

E havia um pensador que era lido avidamente por boa parte desses jovens. De origem judaica, alemão que migrou para os Estados Unidos por causa da perseguição do nazismo, seu nome era Herbert Marcuse. Tinha formação hegeliana e marxista, mas matizada pelos estudos com Martin Heidegger na primeira metade do século XX. Nos anos 1950, a novidade que ele trazia era o estudo filosófico da psicanálise de Freud, ressaltando seu sentido histórico, social, e não só a estrutura essencial da formação subjetiva do indivíduo. O resultado foi Eros e civilização, uma obra preciosa para os jovens dos anos 1960, que misturava aspectos marxistas da teoria crítica da Escola de Frankfurt com a psicanálise freudiana. O objetivo principal, de apelo óbvio para os estudantes, era mostrar que muito da repressão social era apenas uma etapa histórica da cultura, que poderia ser superada dando mais espaço para o princípio do prazer.

Marcuse discute, em Eros e civilização, a tese proposta por Freud de que todo projeto civilizatório depende da subjugação de instintos ou pulsões, pois os benefícios do progresso viriam acompanhados de sofrimento para os indivíduos, que precisariam abrir mão de sua busca pelo prazer imediato. Haveria, de acordo com essa tese, uma identificação da civilização com a repressão, pois aquela exigiria uma diminuição da liberdade individual de procurar a realização das próprias pulsões, mesmo que as de vida. O princípio do prazer, então, seria substituído pelo princípio de realidade, já que o primeiro entra em conflito com o meio natural e humano. Seria de forma traumática que o indivíduo se daria conta de que a plena satisfação indolor das suas necessidades não é possível na realidade. O que Marcuse pretende, em seu livro, é achar, a partir da obra tardia de Freud, subsídios para reverter tal tese. Seu objetivo era desvincular civilização e repressão, provando, ao contrário, que a civilização pode estar em conjunção com o princípio do prazer, com Eros. 
A importância de tal objetivo, para Marcuse, explicitava-se, inclusive, porque o princípio de realidade, de qualquer forma, jamais triunfa completamente sobre o princípio do prazer. O que a civilização reprime continua a existir nela própria, pois "o inconsciente retém os objetivos do princípio do prazer derrotado" (Marcuse, 1978: 36). Logo, a realidade que pretende ter superado o princípio do prazer em prol do progresso é surpreendida, volta e meia, pelo retorno do reprimido, do recalcado. Tal situação seria o resultado da luta eterna do homem pela sua existência, já que, diante das carências e demandas concretas, ele precisa reprimir seus desejos diretos em prol dos meios para sustentar a vida através do trabalho que se faz em sociedade. Essa seria a justificativa racional para a repressão, que Freud, longe de ter inventado, apenas retomou da tradição ocidental de pensamento.

Eis, entretanto, a virada da posição de Marcuse, que se dá com o conceito de "mais-repressão". Se a repressão, como pensou Freud, é necessária para instituir a civilização pelo princípio de realidade, há ainda, contudo, uma repressão que escapa dessa, que vai além do que seria preciso para a vida em sociedade. É uma repressão a mais do que aquela primeira. Sua raiz não é a necessidade de dominação do homem sobre a natureza, que o progresso tecnológico ocidental já conquistou, tornando viável a hipótese de Marx da "abolição do trabalho". Sua raiz é a dominação do homem pelo homem. Os exemplos dados por Marcuse dessa repressão adicional deixam clara qual a atração que suas ideias exerciam sobre os jovens da década de 1960: a perpetuação da família patriarcal-monogâmica, a divisão hierárquica do trabalho e o controle da existência privada do indivíduo pelo público (Marcuse, 1978: 53). Ora, tais restrições não são filogenéticas, biológicas, mas suplementares, históricas. Elas dizem respeito a instituições, como as nossas, com um princípio de realidade configurado socialmente, mas não são necessárias para qualquer civilização. Logo, podem vir a ser superadas.

O forte apelo de tal filosofia estava em mostrar que os empecilhos ao prazer do indivíduo não são necessários para que se evite a barbárie, ou o são em menor grau do que se crê. Para a juventude da década de 1960, isso era música para os ouvidos, pois se combinava com a cultura nascente, para a qual o erotismo do corpo era muito relevante. $\mathrm{O}$ experimentalismo dos jovens - do qual as drogas eram só uma parte, e talvez nem a maior, pois havia o rock e o sexo - sofria resistência dos adultos, que viam aí, em geral, afronta ao princípio de realidade. Com a leitura de Marcuse, os jovens podiam argumentar: afrontamos apenas o princípio de realidade deste mundo adulto atual, que não prezamos mesmo. Tal mundo seria guiado por um "princípio de desempenho" que exige performances cada vez mais eficientes. "Os homens não vivem sua própria vida, mas desempenham tão-só funções preestabelecidas”, escreve Marcuse, completando ainda que, “en- 
quanto trabalham, não satisfazem suas próprias necessidades e faculdades, mas trabalham em alienação" (1978: 58).

O trabalho alienado não dá gratificação, não dá prazer, embora ocupe a maior parte do tempo da vida. O que acontece é que a libido do indivíduo é desviada para desempenhos úteis na sociedade, fazendo com que ele trabalhe para si somente na medida em que trabalha para o sistema, empenhando-se em atividades que, em geral, não coincidem com seus desejos próprios. É fácil imaginar estudantes dos anos 1960 enxergando seus pais como homens engolfados por esse sistema, trabalhando em ocupações que não correspondiam aos seus desejos, mas só à utilidade. Inicia-se um conflito de gerações, formulado conceitualmente e experimentado historicamente nos anos 1960 com uma fúria sem precedentes. Os mais velhos desempenham papéis sociais previstos pelo princípio de realidade dominante do industrialismo avançado. Os jovens, ou ao menos muitos deles, seguem o princípio do prazer e criticam aquele princípio de realidade, que só deixa para tal prazer o breve tempo do lazer.

No caso da sexualidade, segundo Marcuse, ficaria nítido o quanto o prazer é reprimido além do necessário. Embora o sexo seja polimorfo, com várias formas, a organização social interdita a maioria como perversões, por não terem o desempenho esperado: a reprodução da espécie. Se é assim, a exploração da sexualidade por jovens nos anos 1960, ajudada pelas pílulas anticoncepcionais, tinha um aspecto político de rebelião do prazer contra a ordem da procriação que o subjuga e as instituições dessa ordem. Enquanto a sociedade empregava o sexo como meio para um fim, a perversão afirmava o sexo livre, como fim em si, exigindo ainda a participação da fantasia, que, ao contrário da razão, era relegada pelo princípio de desempenho.

Nisso, o sexo é como a arte, pois liga o inconsciente ao consciente, o sonho à realidade, ajudando a restituir a força completa do ego, contra a divisão entre razão (desagradável, mas útil e correta) e fantasia (lúdica, mas inverídica). Se a fantasia da arte fala na linguagem do princípio do prazer, sua autonomia diante do princípio do desempenho repressivo é já seu caráter social crítico. Novamente, temos uma filosofia atraente para os jovens que se queriam na vanguarda estética sem deixar de criticar os valores burgueses, como Hélio Oiticica, que se impressionou ao ler Marcuse.

É que os problemas estariam justamente na civilização burguesa. "Os campos de concentração, extermínio em massa, guerras mundiais e bombas atômicas não são 'recaídas no barbarismo', mas a implementação irreprimida das conquistas da ciência moderna, da tecnologia e dominação dos nossos tempos", afirma Marcuse, embora ele conceba que se trata aí somente de "uma regressão incidental, transitória, na senda do progresso" (1978: 27-28). Defende-se ainda, portanto, o progresso, que seria capaz de superar esse momento desvirtuado. 
Marcuse comenta que "a negação do princípio de desempenho emerge não contra, mas com o progresso da racionalidade consciente, pressupõe a mais alta maturidade da civilização" (1978: 139).

O objetivo, aqui, seria reorientar o progresso, fazendo com que ele tornasse a civilização compatível com a liberdade, a razão com a fantasia, o que eliminaria a repressão além da necessária. O tom de Eros e civilização é otimista. O próprio autor, porém, ao escrever em 1966 novo prefácio para a obra dos anos 1950 , corrige tal tom, admitindo ter minimizado o fato de que as "forças que tornaram a sociedade capaz de amenizar a luta pela existência serviram para reprimir nos indivíduos a necessidade de tal libertação" (Marcuse, 1978: 13). Nasciam novas formas de controle social, cuja expressão emblemática seria o que Marcuse chamou, em obra de 1964, de "homem unidimensional", apontando que até então se confiava que a tradução das capacidades técnicas em realidade traria a revolução, mas a "introjeção democrática suprimiu o sujeito histórico, o agente da revolução: as pessoas livres não necessitam de libertação e as oprimidas não são suficientemente fortes para libertarem-se" (1978: 16).

Nessas condições, o conceito de utopia ganha novos contornos: a libertação dos indivíduos, embora seja a possibilidade histórica mais realista e concreta de um lado, torna-se também muito abstrata e remota de outro lado, pois reprimida através de uma servidão voluntária, compensadora, agradável ao paladar. Sob a repressão do todo social, a liberdade seria transformada em dominação. Embora o indivíduo tenha livre escolha no capitalismo avançado, aquilo que pode ser escolhido por ele já está determinado. Em meio à diversidade aparente, domina o que é unidimensional, pois produtos e serviços sustentam o mesmo sistema social, que, ao buscar a melhoria quantitativa de si, fica imune a transformações qualitativas. Mercadorias e meios de comunicação de massa trazem atitudes e hábitos prescritos, prendendo consumidores agradavelmente a produtores e, assim, ao todo. A liberdade é manipulada, tendo valor ideológico, no sentido que Marx deu ao termo, um discurso encobridor da verdade.

Marcuse, portanto, jamais afirmou que os homens se teriam tornado iguais na sociedade moderna, e sim que seu comportamento e seu pensamento se moveriam em apenas uma dimensão, a do consumo. O dado novo é a tecnologia, que cria formas eficazes de controle e contribui para a administração total, talvez totalitária, da vida, pois, embora sem a política terrorista, a coordenação técnica e econômica manipula as necessidades, impedindo a oposição ao todo social. São minadas as chances da crítica que é negação do estado de coisas. Sem ser negativo nesse sentido, o pensamento fica refém do que já está positivamente dado, dos fatos estabelecidos.

Muitos anos antes, Marcuse já escrevera, ao explicar a filosofia de Hegel, que o homem "não está, pois, à mercê dos fatos que o cercam, mas é capaz de su- 
jeitá-los a um critério mais alto, ao critério da razão" (2004: 17). Seria preciso distinguir entre "é" e "deve ser". Cabe à teoria transcender o fato como é para, através da sua negação conceitual, mostrar que a realidade deve ser mudada. Essa foi a justificativa filosófica do século XIX para as revoluções. Marcuse aprende com a dialética que a realidade factual positiva não tem direito à última palavra, já que “os fatores dos fatos não são dados imediatos da observação". São matéria do pensamento.

O que estava em jogo era manter o papel da filosofia como possibilidade de mudança no mundo. E com cunho realista. Marcuse critica as utopias pela conotação de impossibilidade (1969). Tratava-se de enfatizar transformações exigidas não só no nível geral, mas no particular, com a arte, o erotismo. Os jovens sentiam-se atraídos pela manutenção do ideal revolucionário que não esquecia a sensibilidade individual. Os escritos de Marcuse, desde a década de 1950, inspiraram o espírito contestador da década de 1960. No jargão infeliz que se consagrou, ele foi o "guru" da geração. Mas não foi o único a ter relevância para a época, como prova a situação do outro lado do Atlântico, onde um novo pensador começava a escrever: Michel Foucault.

\section{Michel Foucault e a descontinuidade da história}

Michel Foucault tornou-se filosoficamente conhecido, em grande parte, por suas análises sobre o poder. Entretanto, seus escritos da década de 1960 quase não falam desse tema, sendo devotados a uma arqueologia dos saberes. Nessa medida, a contribuição de Foucault nos anos 1960 e para os anos 1960 não enfatizou o problema do poder, mas sugeriu, isso sim, um novo modo de pensar a história, desenvolvido sobretudo na História da loucura, em $O$ nascimento da clínica e em As palavras e as coisas. Diga-se de passagem que, inversamente, é provável que os acontecimentos do final dos anos 1960 é que tenham contribuído para que, na década seguinte, Foucault pesquisasse a genealogia do poder, uma nova fase de sua filosofia.

Embora os protestos norte-americanos tenham precedido cronologicamente os da França, que só vieram em 1968, foram os do país europeu que passaram à história como símbolo daquela época e de seu caráter rebelde. Quando ocorreu o "Maio de 68", os estudantes foram protagonistas, como nos Estados Unidos, mas o movimento de greves teve maior amplitude, envolvendo não apenas simpatia pelas rebeliões anticoloniais de países pobres, mas reivindicações sindicais trabalhistas. Salas de aula estavam em jogo, mas fábricas também. O momento político era marcado por críticas esquerdistas ao governo, embora o Partido Comunista fosse relutante em apoiá-las, devido à sua confusão anárqui- 
ca. O contexto todo parecia exigir o que Foucault faria mais tarde: uma análise da nova dinâmica social do poder, menos centralizada do que a clássica, não só preocupada com o Estado, e sim mais dispersa, variada. Isso, contudo, como se disse, é outra história, a da obra de Foucault já nos anos 1970. O que vamos acompanhar, nos anos 1960, é o desenvolvimento da pesquisa histórica que tornou Foucault um filósofo digno de atenção pela primeira vez.

No começo da trajetória de Foucault, o que havia de afinado com a época era a tentativa de entender como a história poderia ter mudado, até drasticamente, sem implicar um progresso, ou seja, uma melhoria. Com isso, entrevia-se a possibilidade de recusar a civilização moderna ocidental como o ponto ótimo de chegada do esforço humano. O raciocínio é bem claro. Durante a modernidade, desde o século XVIII pelo menos, o valor positivo das transformações, como aquelas advindas das revoluções, símbolo político dessa época, tinha como justificativa ideológica a evolução. Fazia sentido mudar porque cada mudança significava uma etapa vencida no progresso para um futuro melhor dentro de uma história concebida filosoficamente como linear e contínua. Por sua vez, Foucault desmistifica esse progresso, e avalia as mudanças só como mudanças, sem que signifiquem atraso ou avanço civilizacional.

Desse ponto de vista, a filosofia de Foucault herda, do projeto epistemológico francês de Bachelard, Koyré e Canguilhem, o ensinamento sobre a historicidade das ciências, embora o desloque para a questão dos saberes do homem em geral, sem se deter nos que estudam a natureza, o que implicou, também, abandonar a racionalidade como critério de avaliação (Machado, 1981). Isso foi a grande novidade da arqueologia do saber. Não por acaso, então, ela começa fazendo uma história da loucura. Dizer que a loucura tem uma história, por si só, é suspeitar da universalidade da razão, pois esta dependeria de que seu outro, pelo qual ela se define por contraste, também fosse universal, ou seja, invariável. Em última instância, se a loucura possui uma história, então a razão também possui, o que ameaça sua presunção metafísica reguladora. Pode-se dizer que a escolha da loucura como primeiro objeto de estudo, por Foucault, é estratégica, pois toca no ponto nevrálgico da constituição da ciência como detentora da verdade objetiva na modernidade.

$\mathrm{Na}$ História da loucura, a psiquiatria não é o momento em que se descobre a essência da loucura e o modo de tratá-la, mas sim o discurso, de caráter científico, que a classifica psicologicamente como doença mental, o que até então era impossível, pois a psicologia não existia na época clássica (Foucault, 1999: 337), ela é uma invenção moderna. Até a Revolução Francesa e as idéias de Pinel e Esquirol, a racionalidade médica qualificava a loucura só como doença, sem especificar que era mental. E não há privilégio, para Foucault, do discurso da ciência moderna sobre outros. Logo, a psiquiatria, em vez de definir seu objeto de 
pesquisa, a loucura, torna-se um momento do estudo mais amplo de tal objeto, que circula por diferentes saberes.

O intento de Foucault é explicitar as descontinuidades na história da loucura e chamar atenção para as continuidades. Do mundo clássico ao moderno, observam-se duas mudanças. Na teoria, a loucura passa de doença a doença mental. Na prática, o louco vai da clausura ao hospício. Há, porém, uma decisiva continuidade: a submissão da desrazão à razão, a busca de dominação da loucura. No passado, estão as condições de possibilidade para a exclusão social que a objetividade psiquiátrica faz com o louco. Só nesse sentido a psiquiatria é resultado de um progresso. Sem partilhar a linguagem científica, Foucault pode apontar a origem não científica da ciência psiquiátrica.

Em O nascimento da clínica, a distinção entre a época clássica e a moderna incide sobre a medicina (Foucault, 2011), mas não para opor o passado ingênuo ao presente sábio, e sim para apontar a descontinuidade entre eles. A medicina clássica e a moderna não são distintas em grau, e sim em natureza, o que as faz incomparáveis. Os pressupostos que as orientam são diversos, tornando impossível dizer que uma está errada e a outra certa, pois o critério de erro e acerto é diferente para cada uma. Em geral, porém, aplica-se o critério moderno sobre o clássico, e aí o resultado só pode ser um: a superioridade do presente sobre aquele passado.

É verdade que Foucault, defendendo-se de críticas por dar excessivo relevo às rupturas, chegou a observar em 1967: "o que eu quis estabelecer é justo o contrário de uma descontinuidade, já que evidenciei a própria forma da passagem de um estado ao outro" (Foucault, 2005: 66). Em 1968, contudo, ele é claro ao reiterar que, embora queira explicar as passagens, elas não são contínuas, não há um acúmulo de saber no tempo. Na história clássica, "a descontinuidade era o estigma da dispersão temporal que o historiador tinha o encargo de suprimir da história", escreve, completando, porém, que "ela se tornou, atualmente, um dos elementos fundamentais da análise histórica" (Foucault, 2005: 84). O valor da descontinuidade temporal foi invertido: de obstáculo a prática, de fatalidade exterior a conceito operatório, de negativo a positivo. Note-se ainda que outra inovação de método dessa historiografia descontínua é cruzar discursos teóricos e práticas sociais, tendo em vista, por exemplo, o que se diz sobre a loucura, mas também como o louco era concretamente tratado.

Em As palavras e as coisas, o mais belo livro da arqueologia do saber, o que está em causa é a descontinuidade que deu origem às ciências do homem. Não é um acaso que tais ciências surjam apenas na modernidade. Só poderia ser assim, pois, de acordo com Foucault, a condição de possibilidade delas foi a abertura histórica da filosofia de Kant, já no século XVIII, quando o homem descobre a si como objeto do conhecimento, enquanto no mundo clássico ele ainda era exclu- 
sivamente o sujeito do conhecimento. Sem essa premissa reflexiva, do homem voltando-se sobre si mesmo como objeto, fazer ciências humanas seria um absurdo impensável, já que o conceito de ciência estava voltado para a natureza. Psicologia, sociologia ou antropologia são saberes modernos, mas não porque $o$ mundo clássico não conseguiu criá-los antes devido a seu atraso no progresso humano, e sim porque eram conceitos outros que o orientavam, para os quais não fariam sentido saberes como esses.

A conclusão da argumentação de Foucault "é que o homem não é o mais velho problema nem o mais constante que se tenha colocado ao saber humano" (Foucault, 1999: 536). Sua arqueologia pretende ter mostrado que, cronologicamente, os saberes têm uma história mais longa em torno de outros objetos. E o surgimento do homem em tal história recente não é liberação, conquista de consciência luminosa, acesso à objetividade, superação de crenças ingênuas, mas apenas o efeito da transformação na disposição fundamental dos saberes. Não se trata do triunfo sobre o passado, mas de uma descontinuidade histórica. No fim de suas análises, Foucault aponta, o que não era comum até aqui, o significado dessa constatação para o futuro, e não apenas para o presente. Se o homem, como ele diz, é uma "invenção recente", também pode ter "fim próximo", isto é, se a disposição formada na curva do século XIX desaparecer como apareceu, "então se pode apostar que o homem se desvaneceria, como, na orla do mar, um rosto de areia" (Foucault, 1999: 536).

Influenciado por Nietzsche, Foucault está, aqui, dando sua versão da sentença famosa sobre a morte de Deus (Nietzsche, 2011: 233). Para ele, o que está ameaçado, se perdermos a estruturação dos saberes modernos, é o próprio homem, o que também não parece ser grave, já que se trata apenas de uma transformação histórica na forma pela qual os saberes são organizados, e não qualquer terror apocalíptico sobre o ser humano. Nietzsche, aliás, foi talvez a eminência parda da década de 1960, sobretudo na França, onde inspirou muitos pensadores. Foucault não foi exceção. "Nietzsche constituiu um corte na história do pensamento ocidental”, escreve (2005: 32). Note-se que, novamente, está sendo valorizado o corte, a descontinuidade. Por vezes, Foucault empregou a expressão "corte epistemológico", por exemplo ao pensar Marx do ponto de vista político, mas não econômico, no qual ele se encontraria na linha de David Ricardo (2005: 64-65). Nietzsche seria um corte na própria filosofia. E por quê?

Como Freud e Marx, Nietzsche não teria descoberto novos signos do mundo ocidental e nem dado sentido ao que antes não tinha. $\mathrm{O}$ que ele fez foi postular que não há tal sentido final e verdadeiro, e que portanto a tarefa da interpretação seria infinita, inacabada, retalhada, mas não por falha do intérprete, e sim pela essência da própria interpretação. Se é assim, Foucault escreve, "nada há de absolutamente primeiro a interpretar, pois no fundo tudo já é interpreta- 
ção: cada signo é nele mesmo não a coisa que se oferece à interpretação, mas interpretação de outros signos" (2005: 47). Em suma, não há um significado original aguardando ser interpretado pelo filósofo, assim como não há um passado factual esperando ser descoberto pelo historiador. Tanto um quanto outro já estão sempre em meio ao inacabável trabalho de interpretação.

\section{A interpretação e os anos 1960}

Se Foucault está certo, cabe aproveitar agora para fazer uma autorreferência a este ensaio e concluí-lo. Não se tratou aqui de procurar os verdadeiros fatos dos anos 1960, nem os puros fatos filosóficos. Se não há significado original e tudo é interpretação, a década de 1960 o demonstra em altíssimo grau, por conta das tantas interpretações que recebeu. Estas só não foram exaustivas porque, se não há verdade final, tal noção perde seu sentido: "de fato, a interpretação não esclarece uma matéria a interpretar, que se oferecia a ela passivamente; ela pode apenas apoderar-se, e violentamente, de uma interpretação já ali, que ela deve subverter, revirar, quebrar a marteladas", escreve Foucault (2005: 47). Os anos 1960 já são interpretados quando este ensaio os interpreta. Não se tratou de progredir no conhecimento sobre a época, como se fôssemos tomar consciência da sua verdade. Isso seria confiar na história contínua para a qual "o tempo é concebido em termos de totalização, e a revolução nada mais é do que uma tomada de consciência" (Foucault, 2005: 86).

Não há dúvida de que, pelo caminho, muito ficou por dizer sobre a filosofia e os anos 1960, mas muito também foi dito. O ensaio foi sobre a filosofia $e$ essa década, mais do que sobre a filosofia nessa década, e por isso deu-se destaque a pensadores que não apenas escreveram no período, mas que com ele se relacionaram intimamente, como Marcuse e Foucault. Com tais autores, os anos 1960 não só mudaram alguns paradigmas, mas, sobretudo, criaram a possibilidade de pensar a história em termos de mudança de paradigmas. Foucault falava "de um tipo de filosofia estruturalista, que poderia ser definida como a atividade que permite diagnosticar o que é a atualidade" (2005: 58). No mais, as omissões eventuais deste ensaio confirmam o que seria a verdade de qualquer modo, a saber, que "a interpretação se confronta com a obrigação de interpretar a si mesma infinitamente, de sempre se retomar" (Foucault, 2005: 49). Desse ponto de vista, não foi só o ano de 1968 que não terminou, mas todo e qualquer ano, ou década, que seja objeto de interpretação, pois é ela que jamais termina. 
Referências bibliográficas

ARENDT, Hannah. Origens do totalitarismo. São Paulo: Companhia das Letras, 1998.

. Crises da república. $2^{\mathrm{a}}$ ed. São Paulo: Perspectiva, 1999.

. Sobre a revolução. São Paulo: Companhia das Letras, 2011.

FOUCAULT, Michel. As palavras e as coisas. $8^{\mathrm{a}}$ ed. São Paulo: Martins Fontes, 1999.

- História da loucura. $6^{\mathrm{a}}$ ed. São Paulo: Perspectiva, 1999.

. Arqueologia das ciências e história dos sistemas de pensamento. $2^{\mathrm{a}}$ ed. Rio de Janeiro: Forense Universitária, 2005.

- O nascimento da clínica. $7^{\mathrm{a}}$ ed. Rio de Janeiro: Forense Universitária, 2011.

GASPARI, Élio. A ditadura envergonhada. São Paulo: Companhia das Letras, 2002a.

. A ditadura escancarada. São Paulo: Companhia das Letras, 2002b.

KANT, Immanuel. Ideia de uma história universal de um ponto de vista cosmopolita. $2^{\mathrm{a}}$ ed. São Paulo: Martins Fontes, 2004.

KUHN, Thomas S. A estrutura das revoluções científicas. São Paulo: Perspectiva, 1999.

MACHADO, Roberto. Ciência e saber: a trajetória arqueológica de Foucault. $1^{\mathrm{a}}$ ed. Rio de Janeiro: Graal, 1981.
MARCUSE, Herbert. Ideologia da sociedade industrial. Rio de Janeiro: Zahar Editores, 1967.

Paz e Terra, 1969.

. Eros e civilização: uma interpretação filosófica do pensamento de Freud. $7^{\mathrm{a}}$ ed. Rio de Janeiro: Zahar Editores, 1978.

- Razão e revolução: Hegel e o advento da teoria social. $5^{\mathrm{a}}$ ed. São Paulo: Paz e Terra, 2004.

NIETZSCHE, Friedrich. A gaia ciência. São Paulo: Companhia das Letras, 2001.

PAZ, Octavio. Os filhos do barro: do romantismo à vanguarda. Rio de Janeiro: Nova Fronteira, 1984.

SAVAGE, Jon. A criação da juventude: como $o$ conceito de teenage revolucionou o século $X X$. Rio de Janeiro: Rocco, 2007.

SEARLE, John. Para filósofo, rebeliões estudantis dos anos 60 começaram em Berkeley. Entrevista: http://www1.folha.uol.com. br/folha/mundo/ult94u404879.shtml. Folha Online, 25/5/2008.

STEINER, George. Linguagem e silêncio. São Paulo: Companhia das Letras, 1988.

VENTURA, Zuenir. 1968: o ano que não terminou. Rio de Janeiro: Nova Fronteira, 1988.

\section{Resumo}

O ensaio aponta a relação da filosofia com os anos 1960, tendo em vista os cruzamentos entre idéias então produzidas e aquele momento histórico. $\mathrm{O}$ 
método empregado alia interpretação histórica e interpretação filosófica, com destaque para alguns autores, como Herbert Marcuse e Michel Foucault.

Conclui-se que o pensamento dos anos 1960 cunhou também uma concepção nova do que seria a própria atividade de interpretar, fatos ou idéias.

Palavras-chave: revolução; rebelião; interpretação; Marcuse; Foucault.

\section{Abstract}

This essay describes the interaction of philosophy with the 1960s, considering the intersections between the ideas produced at that time and that particular historic moment. The method combines historical interpretation and philosophical interpretation, highlighting authors such as Herbert Marcuse and Michel Foucault. It concludes that 1960s thinking also coined a new conception of what would be the very activity of interpreting, either facts or ideas.

Key-words: revolution; rebellion; interpretation; Marcuse; Foucault.

\section{Résumé}

L'essai indique le rapport entre la philosophie et les annés 1960, en tenant compte des intersections entre les idées produites alors et le contexte historique de l'époque. La méthode allie l'interprétation historique et l'interprétation philosophique, mettant en lumière certains auteurs comme Herbert Marcuse et Michel Foucault. La conclusion est que la pensée des années 1960 a produit aussi une nouvelle conception de ce que serait l'acte même d'interpréter, soit des faits, soit des idées.

Mots-clés: révolution; rébellion; interprétation; Marcuse; Foucault. 